\title{
Pelayanan Publik Pemerintah Provinsi Daerah Istimewa Yogyakarta Melalui Efektivitas Content Website
}

\author{
Mochamad Hanafi \\ Fakultas Ekonomi, Universitas Negeri Yogyakarta, Indonesia \\ m.hanafi@uny.ac.id
}

\begin{abstract}
Abstrak: Pelayanan Publik Pemerintah Provinsi Daerah Istimewa Yogyakarta Melalui Efektivitas Content Website. Pelayanan yang baik dapat memberikan manfaat bagi pengguna. Penelitian ini bertujuan untuk menganalisis pelayanan publik Pemerintah Provinsi Daerah Istimewa Yogyakarta (DIY) melalui efektivitas konten website. Penelitian ini menggunakan deskriptif kualitatif untuk mendapatkan informasi pelayanan publik melalui website content. Deskripsi penelitian ini adalah hasil dari analisis wawancara dan dokumentasi. Hasil penelitian menunjukkan website content sudah cukup efektif dalam penyelenggaran pelayanan. Pemerintah telah berusaha melayani kebutuhan spesifik dari berbagai kalangan walaupun belum dapat terwujud secara maksimal untuk menciptakan pelayanan publik prima. Konten website bertujuan untuk pencapian visi, misi, dan tujuan Pemerintah Provinsi DIY. Relasi antara pemerintah dan audience telah terjalin secara kuat terutama audience pemerintah. Komunikasi dengan pemerintah dapat dilakukan dengan cepat dan murah. Selain itu, website dapat menunjang demokrasi pemerintah sehingga kepercayaan publik meningkat melalui keterbukaan. Pemerintah diharapkan dapat terus berusaha mengembangkan konten website secara efektif
\end{abstract}

Kata kunci: pelayanan; Yogyakarta; website; komunikasi

Abstract: Public Services of Yogyakarta Special Regional Province Government trough The Website Content Effectiveness. Good service can provide benefits for users. This study aims to analyze public services of the Government of the Special Province of Yogyakarta (DIY) through the effectiveness of website content. This study used descriptive qualitative to obtain information on public services through website content. The description of this research is the result of interview analysis and documentation. The results show that website content was quite effective in providing services. The government has tried to serve the specific needs of various groups although it has not been maximally implemented to create excellent public services. Website content aims to achieve the vision, mission, and goals of the Provincial Government of DIY. The relationship between the government and the audience has been strong, especially the government audience. Audience can communicate with the government quickly and cheaply. Furthermore, in order to increase public trust, website can support government democracy through openness. It is hoped that the government will continue to strive to develop effective website content

Keyword: service; Yogyakarta; website; communication

History \& License of Article Publication:

Received: 04/03/2020 Revision: 11/06/2020 Published: 31/08/2020

DOI: https://doi.org/10.21831/efisiensi.v17i2.30486

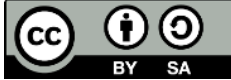

This work is licensed under a Creative Commons Attribution-ShareAlike 4.0 International License. 


\section{PENDAHULUAN}

Pelayanan yang baik perlu dilakukan oleh penyelenggara pelayanan, sehingga dapat menimbulkan kemanfaatan bagi pengguna. Kualitas merupakan sesuatu yang sangat penting bukan hanya sekedar pilihan (Burton \& Sanderson, 2018). Tujuan utama dari good governance yaitu terciptanya pemerintahan yang dapat menjamin pelayanan publik berlandaskan akuntabilitas, transparansi, peraturan hukum, orientasi konsensus, efektivitas, dan efisiensi (Rahim, 2019). Pelayanan publik merupakan segala bentuk pelayanan yang dilakukan oleh instansi pemerintah baik di pusat, di daerah, maupun di lingkungan Badan Usaha Milik Negara (BUMN) atau Badan Usaha Milik Daerah (BUMD) dalam bentuk barang dan atau jasa, baik untuk upaya pemenuhan kebutuhan masyarakat maupun untuk pelaksanaan ketentuan peraturan perundang-undangan (Hardiansyah, 2011). UndangUndang Nomor 25 Tahun 2009, menyatakan bahwa pelayanan publik adalah kegiatan atau rangkaian kegiatan dalam rangka pemenuhan kebutuhan pelayanan sesuai dengan peraturan perundang-undangan bagi setiap warga negara dan penduduk atas barang, jasa dan atau pelayanan administratif yang disediakan oleh penyelenggara pelayanan publik.

Organisasi pelayanan publik perlu untuk mengambil pendekatan relasional dan layanan publik yang dominan dengan menekankan tiga elemen, yaitu membangun hubungan di seluruh sistem penyediaan layanan publik, memahami bahwa keberlanjutan berasal dari transformasi pengetahuan pengguna, dan pemahaman profesional tentang proses pengiriman layanan publik yang didasarkan pada co-produksi yang dapat dilakukan dengan pengguna layanan (Osborne et al., 2015). Penyelengara pelayanan publik tidak hanya dilakukan oleh negara, melainkan dilakukan oleh beberapa pihak, diantaranya lembaga-lembaga publik, lembaga semiswasta, dan lembaga swasta (Ranerup et al., 2016). Pelayanan publik adalah upaya untuk meningkatkan peran serta dan partisipasi masyarakat dalam kebijakankebijakan publik (Wahyuni et al., 2020). Kepentingan publik juga dibutuhkan untuk memahami apa yang menarik bagi publik terhadap layanan publik dan memotivasi pelayanan publik untuk tampil efektif dari waktu ke waktu (Denhardt \& Denhardt, 2015). Pemerintah berperan penting dalam penyediaan pelayanan publik yang prima untuk masyarakatnya sesuai dengan yang tercantum pada pasal 1 Undang-Undang Nomor 25 Tahun 2009 tentang pelayanan publik (Publik \& Indonesia, 2009). Berlakunya kebijakan otonomi daerah, birokrat pemerintah daerah dituntut dapat menyelenggarakan pelayanan publik dengan memperhatikan kebutuhan masyarakat daerahnya. Berkembangnya ilmu pengetahuan dan teknologi menuntut juga pemerintah untuk dapat memberikan pelayanan publik yang efektif (Denhardt \& Denhardt, 2015).

Pelayanan Publik Pemerintah Provinsi Daerah Istimewa Yogyakarta Melalui Efektivitas Content Website 
Penggunaan teknologi informasi dan komunikasi baru dapat memberikan kontribusi signifikan terhadap pemerintah dalam melakukan pelayanan publik terhadap pencapaian tujuan good governance (Heeks, 2020b). Selain itu, teknologi informasi dan komunikasi juga dapat memberikan kontribusi yang berharga untuk pembangunan (Heeks, 2020a). Salah satu cara yang dapat dilakukan oleh pemerintah adalah dengan memanfaatkan internet. Penerapan internet yang digunakan pada lingkungan pemerintahan dinamakan dengan "Electronic Government" (E-government).

E-government merupakan elemen kunci transformasi pemerintah melalui pelayanan sebagai sarana untuk memperbaiki transparansi, akuntabilitas, dan pemerintahan yang baik dengan lebih berorientasi pada hasil, efisien, dan berpusat pada warga negara, serta memungkinkan masyarakat untuk mengakses layanan dan informasi pemerintah seefisien dan seefektif mungkin melalui penggunaan internet dan saluran komunikasi lainnya (Alryalat et al., 2019). E-governance melibatkan penggunaan teknologi informasi dan komunikasi dalam peningkatan fungsi dan kerja internet pemerintah (R. Divya, 2020). Tujuan E-governance adalah untuk menyediakan layanan publik dengan metode yang efisien dan dapat memberikan informasi secara cepat dengan hanya mengklik mouse. $E$ government mempunyai harapan supaya semua tingkat pemerintahan dapat meningkatkan layanan publik, mengurangi biaya, dan meningkatkan proses demokrasi yang tinggi (Hopper et al., 2020).

Meluasnya internet, teknologi seluler, dan jejaring sosial memfasilitasi munculnya konsep keterbukaan data ke publik tanpa biaya dan bebas dari kendala lainnya (Al-Jamal \& Abu-Shanab, 2016). Open government membuka data pemerintah kepada publik dan menyisakan ruang untuk partisipasi, transparansi, dan kolaborasi. Teknologi saat ini semakin memungkinkan pemerintah untuk berbagi berbagai informasi dengan warga sehingga tidak hanya sistem dengan karakteristik kegunaan yang baik, tetapi juga akses tanpa batas untuk masyarakat (De Souza et al., 2016). E-government dapat diklasifikasikan menjadi 4 level, diantaranya: (Sabani et al., 2019)

1. Publikasi yaitu pemerintah hanya mempublikasikan segala jenis informasi maupun data yang bisa diakses oleh masyarakat secara umum, bebas, dan langsung melalui website .

2. Interaksi yaitu pengelola situs website menyediakan layanan yang memungkinkan adanya komunikasi dua arah antara pengakses dan pemerintah.

3. Pengadaan eletronik yaitu mengatur pengadaan barang dan jasa pemerintah secara online.

Pelayanan Publik Pemerintah Provinsi Daerah Istimewa Yogyakarta Melalui Efektivitas Content Website 
4. Integrasi, dimana warga negara dapat bertransaksi dengan semua kantor pemerintah yang telah memiliki basis data pengguna bersama.

Indonesia telah berinisiatif menuju e-government sejak tahun 2001 yang dimuat dalam Instruksi Presiden No. 6 Tahun 2001 tentang Telematika (Telekomunikasi, Media dan Informatika) yang menyatakan bahwa aparat pemerintah harus menggunakan teknologi telematika untuk mendukung good governance dan mempercepat proses demokrasi. Lahirnya Instruksi Presiden No. 3 Tahun 2003 Tentang Kebijakan dan Strategi Nasional Pengembangan E-government merupakan langkah tegas pemerintah dalam proses pemerintahan untuk memanfaatkan teknologi informasi dan komunikasi serta menciptakan masyarakat Indonesia yang berbasis informasi. Untuk meningkatkan efisiensi dan efektivitas penyelenggaraan otonomi daerah, pemerintah daerah perlu memanfaatkan perkembangan teknologi informasi sehingga dapat memperhatikan peluang dan tantangan dalam persaingan global. Implementasi e-government bukan pekerjaan mudah karena banyak tantangan dan hambatan yang harus diperlakukan sangat hati-hati (Alshehri \& Drew, 2010).

Website adalah wujud perkembangan teknologi informasi yang efektif untuk melakukan publikasi. Website merupakan salah satu sarana masyarakat supaya mudah untuk mengakses berbagai informasi. Website berisi halaman yang memuat informasi dalam bentuk teks, gambar, audio, video maupun animasi yang dapat diakses masyarakat umum (Pudjiarti et al., 2019). Halaman web tersebut harus diisi dengan konten yang efektif sehingga perlunya efektivitas pada konten website untuk pelayanan kepada penguna.

Efektivitas merupakan akurasi dan kelengkapan sehingga pengguna dapat mencapai tujuan yang telah ditentukan (Kous et al., 2020). Untuk itu, pemerintah daerah perlu mempunyai website dalam rangka pelaksanaan e-government. Adanya otonomi daerah pada dasarnya bertujuan untuk meningkatkan pelayanan publik sehingga dapat mempercepat terwujudnya kesejahteraan masyarakat dan sebagai sarana pendidikan politik di tingkat lokal. Oleh karena itu, pemerintah perlu selalu melakukan inovasi pada e-government (Heeks \& Santos, 2020).

Congressional Management Foundation yang meneliti 605 website pemerintahan di Amerika menyimpulkan bahwa ada beberapa aspek penting yang menjadi pertimbangan oleh pembuat website pemerintahan agar teknologi tersebut memenuhi fungsi dari $e$ government. Terdapat lima faktor yang menjadi dasar dari pembuatan website e-goverment, diantaranya audience, content, interactivity, usability, innovation_(Indrajit, 2007). Website pemerintah pada dasarnya sebagai penyedia informasi bagi audience. Interaksi 
memungkinkan ada dalam website untuk penyelenggaraan komunikasi. Penggunaan yang mudah terhadap website juga sangat diharapkan oleh pengguna. Untuk dapat menyesuaikan dengan perkembangan maka diperlukan inovasi terhadap website. Untuk dapat mewujudkan hal tersebut, pengelola perlu mengefektifkan konten website.

Konten website merupakan inti dari sebuah website, yang nantinya akan disampaikan kepada audience melalui website. Penyelenggaraan pelayanan publik yang dilakukan oleh pemerintah baik pusat maupun daerah pada kenyataan masih belum dapat mewujudkan pelayanan yang efektif dan efisien. Pelayanan tersebut dapat diketahui dari masih banyaknya pengaduan dari masyarakat sebagai pengguna layanan, baik secara langsung maupun tidak langsung, melalui media massa yang menuntut peningkatan kualitas pelayanan publik pemerintah. Peningkatan kualitas pelayanan publik merupakan isu yang sangat penting karena semakin besarnya tuntutan masyarakat terhadap pelayanan tetapi penyelenggara pelayanan tidak melakukan perubahan yang berarti.

Kualitas layanan e-government memiliki delapan dimensi yang berkontribusi, diantaranya kualitas sistem, keandalan, keamanan, aksesibilitas, kualitas informasi, kemampuan layanan, interaktivitas, dan responsif yang akan mempengaruhi niat masyarakat untuk menggunakan (Li \& Shang, 2020). Beberapa faktor penentu keberhasilan $e$ government ialah posisi keuangan suatu negara dan tingkat e-readiness, fasilitas infrastruktur dan inovasi teknologi, kerangka kerja politik dan hukum, serta pengetahuan lingkungan negara tertentu dan kesadarannya (Glyptis et al., 2020). Penerapan e-government di Kabupaten Sragen dapat meningkatkan pelayanan publik di Kabupaten Sragen (Susena \& Lestari, 2016). Sedangkan website Pemerintah Kabupaten Jombang sudah efektif menjadi media pemberi informasi kepada masyarakat, namun belum efektif sebagai media dalam memberikan pelayanan publik secara elektronik (e-service) (Aprilia et al., 2014). Pelaksanaan e-government untuk pelayanan publik menunjukkan hasil yang berbeda-beda, maka memungkinkan di daerah lain terdapat temuan baru dan hasil yang berbeda.

Provinsi Daerah Istimewa Yogyakarta (DIY) merupakan salah satu pemerintah daerah yang menerapkan e-government dalam memberikan pelayanan kepada masyarakat melalui website. Website merupakan tingkatan pelaksanaan pelayanan dengan e-government dalam menyampaikan informasi atau publikasi. Setelah itu dapat ditingkatkan menjadi interaksi dan transaksi. Untuk dapat mencapai interaksi dan transaksi, pengefektifan pada tingkatan publikasi perlu dilakukan. Pada tingkat publikasi yang paling utama adalah menyediakan informasi sesuai kebutuhan masyarakat. Sedangkan dari observasi awal yang dilakukan, masyarakat masih menganggap bahwa konten website masih kurang lengkap. Penelitian 
tentang content website Pemerintah Provinsi Daerah Istimewa Yogyakarta juga belum dilaksanakan. Sehingga diperlukan kajian tentang pelayanan Pemerintah Provinsi Daerah Istimewa Yogyakarta melalui efektivitas website content.

\section{METODE}

Penelitian yang dilakukan merupakan penelitian deskriptif dengan pendekatan kualitatif. Desain penelitian deskriptif kualitatif dimaksudkan untuk menggali fakta tentang pelayanan publik Pemerintah Provinsi Daerah Istimewa Yogyakarta melalui efektivitas website content. Pengumpulan data dilakukan menggunakan interview guide, recorder, dokumentasi, dan studi kepustakaan untuk mendapatkan data primer mapun sekunder. Teknik yang digunakan untuk menguji kualitas data adalah teknik triangulasi untuk mengkonfirmasi apakah proses dan hasil yang diperoleh sudah dipahami secara benar oleh peneliti berdasarkan apa yang dimaksudkan oleh informan. Untuk menganalisis data, pada penelitian ini digunakan teknik analisis taksonomi yang berfokus pada domain-domain tertentu dilanjutkan memilih domain tersebut menjadi sub-sub domain serta bagian-bagian yang lebih khusus dan terperinci.

\section{HASIL DAN PEMBAHASAN}

\section{Hasil Penelitian}

Pemerintah Provinsi DIY mempunyai website https://www.jogjaprov.go.id sebagai media e-government untuk melayani masyarakat. Berikut hasil penelitian pelayanan Pemerintah Provinsi Daerah Istimewa Yogyakarta melalui efektivitas website content.

1. Pemenuhan kebutuhan audience dan stakeholder

Website Pemerintah Provinsi DIY berusaha untuk memenuhi kebutuhan masyarakat. Berbagai kegiatan dan data ditampilkan dalam website tersebut. Pemerintah provinsi juga bekerja sama dengan pemerintah daerah (kabupaten/ kota) untuk mengisi konten website, walaupun dalam praktiknya mereka lebih fokus kepada website masingmasing. Baik pemerintah provinsi maupun pemerintah kabupaten/ kota belum sepenuhnya menyadari akan pentingnya ketersediaan berbagai informasi bagi masyarakat. Informasi yang sering dimuat adalah agenda kepala daerah dan beberapa kegiatan dinas.

2. Menunjang pencapaian visi, misi, dan tujuan dari pemerintah

Sesuai dengan tujuan Pemerintah Provinsi DIY telah disediakan sarana komunikasi antara pemerintah dengan masyarakat melalui website. Melalui website disampaikan berbagai informasi pelaksanaan tugas pemerintah dan berbagai data yang dibutuhkan pengunjung. Masyarakat sangat senang mengunjungi website untuk 
membaca berbagai artikel yang disediakan pemerintah dan juga media sosial instagram, facebook, dan twitter resmi pemerintah.

3. Relasi yang kuat antara pemerintah dan audience

Website Pemerintah Provinsi DIY mempunyai fitur untuk dapat berkomunikasi degan pengunjung. Setiap artikel di website disediakan kolom komentar atau bisa nantinya pengunjung memberika tanggapannya melalui media masa yang ada. Fitur itu disediakan agar masyarakat dapat memberikan masukan terhadap pemerintah. Adanya masukan membuat pemerintah dapat memperbaiki pelayanannya.

4. Ketertarikan calon pengunjung untuk menjadi pengakses

Pada dasarnya masyarakat tertarik dengan adanya website Pemerintah Provinsi DIY. Mereka juga diarahkan untuk mengunjungi media sosial yang dimiliki pemerintah ketika membuka website. Arahan tersebut dilakukan karena website lebih bersifat formal. Pengunjung website mempunyai selera yang bermacam-macam. Pencari data cukup dengan melihat website yang telah tersedia. Media sosial sangat disukai oleh masyarakat kalangan milenial.

5. Ketersediaan informasi terhadap audience

Pemerintah provinsi telah berusaha untuk menyediakan informasi yang dibutuhkan audience. Informasi telah disediakan untuk berbagai kebutuhan menggunakan subdomain, tetapi terkadang terdapat beberapa yang tidak dapat dibuka sehingga pengunjung tidak mendapat informasi. Website sudah terhubung dengan media sosial walaupun belum secara keseluruhan. Berbagai latar belakang audience akan mengakses informasi sesuai yang dibutuhkan. Calon pekerja, pendidik, pengguna jalan raya, wisatawan, pengguna pelayanan publik, pemuda mencari informasi sesuai keinginannya.

6. Penghematan waktu dan biaya audience

Informasi yang ada pada website belum dapat memenuhi kebutuhan audience. Masih terdapat beberapa data yang diinginkan masyarakat tetapi tidak ada di website. Tidak adanya informasi yang diinginkan di website mengharuskan masyarakat untuk datang ke kantor. Namun, informasi yang saat ini sudah ada di website dapat meminimalisir biaya dan waktu pengguna.

7. Kepercayaan publik terhadap proses keterbukaan

Pelaksanaan tugas dan penggunaan anggaran oleh Pemerintah Provinsi DIY disampaikan melalui website resmi. Setiap kegiatan yang dilakukan oleh pihak Pemerintah Provinsi DIY akan diliput dan disajikan dalam website. Penyampaian Pelayanan Publik Pemerintah Provinsi Daerah Istimewa Yogyakarta Melalui Efektivitas Content Website 
informasi tersebut dimaksudkan untuk keterbukaan pemerintah. Masyarakat dapat mengetahui dan memonitoring pelaksanaan tugas dan penggunaan anggaran. Pemerintah berharap dengan tindakannya tersebut dapat berdampak terhadap kepercayaan masyarakat.

\section{Pembahasan Hasil Penelitian}

Pemerintah Provinsi Daerah Istimewa Yogyakarta mempunyai website https://www.jogjaprov.go.id sebagai media e-government untuk melayani masyarakat. Pemerintah Provinsi DIY mulai mengembangkan website pada tahun 2018 yang dikelola oleh Dinas Komunikasi dan Informatika DIY beserta Biro Umum Humas dan Protokol Pemerintah Provinsi DIY. Pengelolaan tersebut terutama untuk mengisi konten website dan mengembangkan fitur-fitur pada website Pemerintah Provinsi DIY. Kedua kantor tersebut masing-masing mempunyai satu admin yang bekerjasama mengelola website. Tim Humas dan Protokol lebih mengelola konten kegiatan Gubernur DIY dan memposting di website.

Tujuan dari website Pemerintah Provinsi DIY adalah untuk mempublikasikan kinerja pemerintah dan menyampaikan informasi penting kepada masyarakat. Pemerintah mempunyai beberapa layanan yang dilakukan oleh instansi masing-masing atau setiap Satuan Kerja Perangkat Daerah (SKPD). Masing-masing SKPD tersebut membantu dalam pengelolaan website pemerintah provinsi secara tidak langsung melalui portal SKPD. Pengunjung website dapat terhubung ke portal SKPD untuk menemukan informasi yang diperlukan.

Hasil penelitian dan pembahasan ini mengidentifikasi content yang sesuai dengan target awal bagi masyarakat ataupun stakeholder dengan harapan dapat membantu memenuhi kebutuhan user demi menciptakan pelayanan publik yang prima. Setelah menentukan audience website dengan tepat, kemudian dibuat dan dikembangkan "jantung" website tersebut, yaitu isi atau content yang akan dikomunikasikan, baik berupa informasi ataupun pelayanan dari e-goverment. Pemerintah harus membangun content yang sesuai dengan target awal bagi masyarakat ataupun stakeholder dengan harapan dapat membantu memenuhi kebutuhan user demi menciptakan pelayanan publik yang prima. Pemerintah harus mampu membangun website dengan content yang efektif yaitu: (Indrajit, 2007)

1. Pelayanan prima melalui website untuk membantu audience dan stakeholder dalam memenuhi kebutuhannya

2. Konten yang menunjang tercapainya visi, misi, tujuan, dan obyektif dari pemerintah 
3. Pemerintah dapat menjalin hubungan atau relasi yang kuat dengan masyarakat atau audience

4. Menarik perhatian para calon pengunjung agar berminat menjadi audience yang setia untuk mengakses

5. Kebutuhan informasi audience dapat disediakan oleh website

6. Audience dapat menghemat waktu dan biaya untuk berkomunikasi dengan pemerintah

7. Konten yang ada dapat memperkuat keterlibatan masyarakat dalam proses pemerintahan

8. Memperkuat kepercayaan publik dengan proses keterbukaan yang demokratis.

Content yang paling relevan untuk ditampilkan pada website diantaranyaa adalah informasi terkait dengan proses legislatif, isu yang sedang hangat dibicarakan publik, berkaitan dengan aspek akuntabilitas, referensi untuk pendidikan politik, pelayanan kepada konstituen, berita pelaksanaan kegiatan, informasi mengenai anggota legislatif, link sejumlah website yang berhubungan, dan lain-lain. Berikut hasil dan pembahasan mengenai pelayanan Pemerintah Provinsi Daerah Istimewa Yogyakarta melalui efektivitas content website:

1. Pemenuhan kebutuhan audience dan stakeholder

Pemerintah harus dapat membangun website untuk dapat melayani masyarakat dengan prima (Indrajit, 2007). Konten website Pemerintah Provinsi DIY lebih bersifat formal. Website tersebut merupakan media diseminasi informasi kegiatan di lingkungan Pemerintah Provinsi DIY. Konten website Pemerintah Provinsi DIY dapat dikategorikan menjadi dua aspek, yaitu statis dan dinamis. Konten statis adalah konten dengan perubahan dalam jangka waktu yang cukup lama atau jarang berubah, seperti struktur organisasi dan data kebijakan. Sedangkan konten dinamis ialah konten yang sering berubah-ubah atau berubah dalam jangka waktu yang cukup cepat, sebagai contohnya adalah berita. Untuk mendapatkan konten berita, terdapat reporter utama di Biro Humas dan Protokol yang tugasnya meliput berita harian.

Website Pemerintah Provinsi DIY merupakan media penyampaian informasi terkait dengan kegiatan di lingkungannya dan kebijakan baru yang perlu diketahui oleh masyarakat. Mulai tahun 2019, Kominfo telah melibatkan Organisasi Pemerintah Daerah (OPD) yang terdiri dari lembaga di lingkungan pemerintah provinsi DIY, termasuk kabupaten/kota yang ada diwilayah DIY, untuk memasukkan konten berita pada website. Akan tetapi OPD tidak dapat aktif untuk mengisi website karena lebih 
fokus untuk mengisi website pemerintah kabupaten/ kota. OPD belum mempunyai kesadaran bahwa masyarakat membutuhkan pengetahuan tidak hanya di masing-masing kabupaten/ kotanya, tetapi juga secara makro tentang provinsi DIY. Selain itu, isi website cenderung hanya informasi terkait agenda Gubernur DIY, baik berupa kegiatan social, fisik, kerjasama maupun kebijakan baru yang perlu diketahi oleh masyarakat. Selain itu juga kegiatan yang dilakukan oleh dinas terkait seperti bazar, imunisasi, dan pencatatan sipil.

2. Menunjang pencapaian visi, misi, dan tujuan dari pemerintah

Website yang dibangun pemerintah harus dapat menunjang pencapaian visi, misi, dan tujuan pemerintah (Indrajit, 2007). Website ditujukan untuk menunjang tercapaianya visi, misi, dan tujuan organisasi. Visi Pemerintah Provinsi Daerah Istimewa Yogyakarta adalah "Terwujudnya peningkatan kemuliaan martabat manusia Jogja”. Untuk dapat mewujudkan visi tersebut dijabarkan dalam misi diantaranya yang berkaitan dengan pelayanan publik, yaitu penyelenggaraan pemerintahan yang demokratis dan aparatur sipil yang menjunjung tinggi nilai kejujuran, nurani rasa malu, nurani rasa bersalah dan berdosa apabila melakukan penyimpangan-penyimpangan yang berupa korupsi, kolusi, dan nepotisme. Untuk menciptakan pemerintah yang demokratis, pemerintah menyelenggarakan komunikasi dua arah. Pemerintah memberikan informasi yang seluas-luasnya kepada masyarakat. Masyarakat dari berbagai latar belakang antusias terhadap website dengan mencari informasi pada website. Audience milenial juga diarahkan untuk mengikuti media sosial Pemerintah Provinsi DIY, diantaranya instagram, facebook, dan twitter karena di website sifatnya lebih formal. Setiap artikel di website disertakan saluran komunikasi walaupun tidak secara langsung atau menggunakan media sosial untuk menerima tanggapan masyarakat.

3. Relasi yang kuat antara pemerintah dan audience

Website pemerintah harus dapat menciptakan hubungan yang kuat antara pemerintah dan para pengunjung website (Indrajit, 2007). Website akan efektif ketika terdapat interaksi di dalamnya. Interaksi yang ada pada website Pemerintah Provinsi DIY diharapkan dapat tercipta secara dua arah antara pemerintah dan masyarakat untuk perbaikan keduanya. Masyarakat dapat memberikan masukan terhadap pemerintah, kemudian pemerintah memberikan tanggapan atas masukan tersebut. Setiap artikel di website Pemerintah Provinsi DIY dilengkapi dengan saluran komunikasi yang 
disertakan walaupun tidak secara langsung atau menggunakan media lain. Setiap atikel akan disertakan dengan media sosial untuk menerima tanggapan masyarakat.

4. Ketertarikan calon pengunjung untuk menjadi pengakses

Pemerintah harus dapat membuat website yang menarik perhatian calon pengunjung agar dapat setia (Indrajit, 2007). Pemerintah Provinsi DIY dan masyarakat mempunyai keterikatan dalam hal informasi. Masyarakat, baik DIY maupun lainnya, mencari informasi terkait dengan Yogyakarta baik itu terkait Pemerintah Provinsi DIY maupun yang lainnya. Untuk audience milenial, akan diarahkan juga untuk mengikuti media sosial Pemerintah Provinsi DIY diantaranya instagram, facebook, dan twitter.

5. Ketersediaan informasi terhadap audience

Website pemerintah harus dapat menyediakan segala kebutuhan informasi bagi audience (Indrajit, 2007). Website harus dapat menyediakan informasi yang dibutuhkan oleh audience baik masyarakat DIY atau masyarakat lain. Pemerintah Provinsi DIY sudah menentukan audience website sehingga konten yang ada sudah sesuai dengan kebutuhan dan dapat dimanfaatkan oleh audience. Website sudah menyediakan dengan lengkap dan semua data sudah diarahkan ke berbagai sub domain sesuai kebutuhan. Selain itu, website tersebut sudah ada petak-petak dari isi website. Website sudah dapat memenuhi kebutuhan para audience termasuk golongan usia muda dalam mencari berbagai data, event, kebudayaan, kuliner, dan pariwisata. Sehingga ketika membutuhkan data tidak perlu datang ke kantor. Mereka cukup mengakses melalui website. Informasi dapat dicari melalui link yang terhubung, walaupun terdapat beberapa link tidak dapat dibuka sehingga audience tidak mendapatkan informasi yang dibutuhkan.

Audience pencari kerja mengunjungi website untuk mencari informasi lowongan pekerjaan, termasuk CPNS terutama CPNS Pemerintah Provinsi DIY. Pendidik di DIY sering mengakses data pokok pendidikan dan Jogja Belajar untuk menunjang proses pembelajaran. Staf pemerintah DIY aktif mengunjungi konten yang sesuai dengan bagiannya untuk mendukung pekerjaannya. Selain itu, audience menggunakan untuk memantau situasi lalu lintas dengan mengakses Area Traffic Control System (ATCS), sehingga bisa memantau melalui cctv untuk menghindari kemacetan, walaupun di beberapa titik tidak bisa dipantau.

Generasi milenial lebih sering mengakses website untuk topik wisata, pemberitaan, dan pelayanan publik di Pemerintah Provinsi DIY. Konten yang ada sudah cukup up to date sehingga sesuai dengan kebutuhan pencari informasi. Akan tetapi, 
untuk milenial muda masih mengharapkan informasi yang bersifat milenial dan lebih up to date untuk berita kabupaten/ kota. Kewirausahaan dan kearifan lokal saat ini sedang menjadi pembicaraan yang menarik, sehingga audience mengharapkan adanya konten tentang kewirausahaan dan konten lokal yang perlu ditingkatkan.

6. Penghematan waktu dan biaya audience

Kegunaan website pemerintah yaitu agar antara pemerintah dan audience dapat menghemat waktu dan biaya dalam berkomunikasi (Indrajit, 2007). Ketersediaan informasi yang lengkap pada website dapat menghemat waktu dan biaya. Apabila informasi yang dibutuhkan oleh audience telah terpenuhi, maka audience cukup mengunjungi web dan tidak perlu datang ke kantor. Akan tetapi, saat ini belum semua dapat disediakan pada website tersebut oleh pemerintah. Selain itu, terkadang informasi yang tersedia belum sepenuhnya sesuai dengan harapan audience. Dalam kondisi demikian, audience perlu mendatangi kantor untuk mendapatkan informasi. Namun, kebutuhan terhadap konten website yang terpenuhi maka dapat menghemat waktu dan biaya.

7. Keterlibatan publik dalam proses pemerintahan

Adanya website pemerintah harus dapat meningkatan keterlibatan masyarakat dalam proses pemerintahan (Indrajit, 2007). Proses pemerintahan yang baik harus dapat melibatkan masyarakat dalam berbagai hal. Pemerintahan elektronik (e-government) adalah bidang penelitian yang mempelajari penggunaan teknologi informasi dan komunikasi (TIK) di sektor publik. Inisiatif e-government sering dikaitkan dengan janji pemerintah yang transformasional, yang lebih efisien dan memanfaatkan teknologi modern untuk meningkatkan keterlibatan masyarakat dalam proses pemerintah (demokratis) (Sundberg, 2019). Audience harus dapat ikut terlibat dalam proses pemerintahan termasuk pembuatan kebijakan. Audience mempunyai kesadaran untuk memperkuat keterlibatan dalam proses pemerintahan dengan cara memantau informasi pada fitur e-lapor. Keterlibatan tersebut untuk mengetahui kejadian di DIY dan berharap untuk menyelesaikan masalah tersebut. E-lapor diharapkan dapat menjadi fitur unggulan untuk dapat meningkatkan pelayanan pemerintah kepada masyarakat. Proses pembuatan kebijakan pemerintah dari aspirasi masyarakat dapat memperkuat kepercayaan publik melalui proses keterbukaan yang demokratis.

8. Kepercayaan publik terhadap proses keterbukaan

Keterbukaan yang demokratis harus tercipta melalui website pemerintah sehingga memperkuat tingkat kepercayaan masyarakat (Indrajit, 2007). Keterbukaan pemerintah 
sangat diharapkan oleh masyarakat dan juga salah satu wujud dari good governance. Keterbukaan yang dilakukan oleh pemerintah akan menambah kepercayaan publik terhadap pemerintahan. Untuk melaksanakan keterbukaan pemerintah dapat dilakukan dengan berbagai cara. Pemerintah dapat menyampaikan pelaksanaan tugas dan anggaran yang digunakan. Adanya konten pembiayaan pemerintah provinsi DIY pada website bertujuan agar masyarakat dapat mengetahui dan memantaunya sehingga tercipta transparansi anggaran pemerintah. Transparansi dana Pemerintah Provinsi DIY dapat meningkatkan kepercayaan publik. Konten pada website Pemerintah Provinsi DIY dapat menunjang hubungan atau relasi yang baik dengan para pengunjung website.

\section{KESIMPULAN}

Pemerintah telah berusaha untuk melayani sejumlah kebutuhan secara spesifik dari beragam kalangan, walaupun belum dapat terwujud secara maksimal memenuhi kebutuhan untuk menciptakan pelayanan publik yang prima kepada seluruh audience. Konten yang ada pada website bertujuan untuk pencapian visi, misi dan tujuan Pemerintah Provinsi DIY. Relasi antara pemerintah dan audience telah terjalin secara kuat, terutama audience pemerintah. Bebarapa audience, terutama untuk pengunjung generasi milenial, menginginkan konten yang lebih beraneka, seperti data statistik, berita setiap kabupaten/ kota, dan wirausaha yang belum tersedia. Selain itu, perlu adanya perbaikan pada link atau subdomain yang tidak ada kontennya, sehingga tertarik untuk selalu mengakses. Adanya website cukup dapat menghemat waktu dan biaya dari masyarakat atau audience dalam berkomunikasi dengan pemerintah. Website juga dapat memperkuat kepercayaan publik melalui proses keterbukaan yang demokratis. Untuk itu dapat disebutkan bahwa konten website Pemerintah Provinsi DIY sudah cukup efektif dalam penyelenggaran pelayanan Pemerintah Provinsi DIY.

Pemerintah diharapkan dapat terus berusaha mengembangkan konten website seefektif mungkin untuk memudahkan masyarakat dalam mengakses website Pemerintah Provinsi DIY. Sehingga penelitian ini dapat memperbaiki pelayanan oleh Pemerintah Provinsi DIY melalui website. Penelitian ini terbatas pada website content. Untuk dapat mengetahui secara komprehensif pelayanan melalui website oleh Pemerintah Provinsi DIY, maka dapat dilakukan penelitian terkait audience, interactivity, usability, dan website innovation.

\section{DAFTAR PUSTAKA}

Al-Jamal, M., \& Abu-Shanab, E. (2016). The influence of open government on egovernment website: The case of Jordan. International Journal of Electronic 
Governance. https://doi.org/10.1504/IJEG.2016.078131

Alryalat, M. A. A., Rana, N. P., \& Dwivedi, Y. K. (2019). Citizen's Adoption of an EGovernment System. Open Government, 651-674. https://doi.org/10.4018/978-15225-9860-2.ch031

Alshehri, M. A., \& Drew, S. (2010). Implementation of e-Government: Advantages and Challenges. International Conference E-Activity and Leading Technologies 2010.

Aprilia, S., Wijaya, A., \& Suryadi, S. (2014). Efektivitas Website Sebagai Media EGovernment dalam Meningkatkan Pelayanan Elektronik Pemerintah Daerah (Studi Pada Website Pemerintah Daerah Kabupaten Jombang). Wacana, Jurnal Sosial Dan Humaniora. https://doi.org/10.21776/ub.wacana.2014.017.03.3

Burton, M., \& Sanderson, H. (2018). Quality. In Developing and Managing High Quality Services for People with Learning Disabilities. https://doi.org/10.4324/9780429457982-19

De Souza, I. M., Maciel, C., \& Cappelli, C. (2016). The model of accessibility to electronic Government: Applicability in DATAPREV. ACM International Conference Proceeding Series. https://doi.org/10.1145/2912160.2912212

Denhardt, J. V., \& Denhardt, R. B. (2015). The New Public Service Revisited. Public Administration Review. https://doi.org/10.1111/puar.12347

Glyptis, L., Christofi, M., Vrontis, D., Giudice, M. Del, Dimitriou, S., \& Michael, P. (2020). E-Government implementation challenges in small countries: The project manager's perspective. Technological Forecasting and Social Change. https://doi.org/10.1016/j.techfore.2019.119880

Hardiansyah. (2011). Kualitas Pelayanan Publik. KUALITAS PELAYANAN PUBLIK MENUJU GOOD LOCAL GOVERNANCE. https://doi.org/10.1016/j.jhsa.2008.07.013

Heeks, R. (2020a). Most eGovernment-for-Development Projects Fail: How Can Risks be Reduced? SSRN Electronic Journal. https://doi.org/10.2139/ssrn.3540052

Heeks, R. (2020b). Understanding e-Governance for Development. SSRN Electronic Journal. https://doi.org/10.2139/ssrn.3540058

Heeks, R., \& Santos, R. (2020). Understanding Adoption of e-Government: Principals, Agents and Institutional Dualism. SSRN Electronic Journal. https://doi.org/10.2139/ssrn.3540039

Hopper, S. E., Baker, T. H., \& Browning, J. (2020). State and Local Government. In An Arkansas History for Young People. https://doi.org/10.2307/j.ctvw04m79.10

Indrajit, R. E. (2007). Electronic Government in Action: Strategi Implementasi di Berbagai Negara. In APTIKOM.

Kous, K., Pušnik, M., Heričko, M., \& Polančič, G. (2020). Usability evaluation of a library website with different end user groups. Journal of Librarianship and Information Science. https://doi.org/10.1177/0961000618773133

Li, Y., \& Shang, H. (2020). Service quality, perceived value, and citizens' continuous-use intention regarding e-government: Empirical evidence from China. Information and Management. https://doi.org/10.1016/j.im.2019.103197

Osborne, S. P., Radnor, Z., Kinder, T., \& Vidal, I. (2015). The SERVICE Framework: A Public-service-dominant Approach to Sustainable Public Services. British Journal of Management. https://doi.org/10.1111/1467-8551.12094

Publik, P., \& Indonesia, P. R. (2009). UU Nomor 25 Tahun 2009 Tentang"Pelayanan Publik". UU Nomor 25 Tahun 2009 Tentang"Pelayanan Publik".

Pudjiarti, E., Nurlaela, D., \& Sulistyani, W. (2019). Sistem Informasi Penjualan Beras Berbasis Website. Indonesian Journal on Software Engineering (IJSE). https://doi.org/10.31294/ijse.v5i1.5865

R. Divya. (2020). Studies in Indian Place Names A Study on Promotion of Tourism through 
Malayalam Cinema. 40(19), 196-203.

Rahim, A. (2019). Governance and Good Governance-A Conceptual Perspective. Journal of Public Administration and Governance. https://doi.org/10.5296/jpag.v9i3.15417

Ranerup, A., Henriksen, H. Z., \& Hedman, J. (2016). An analysis of business models in Public Service Platforms. Government Information Quarterly. https://doi.org/10.1016/j.giq.2016.01.010

Sabani, A., Deng, H., \& Thai, V. (2019). Evaluating the development of E-government in Indonesia. ACM International Conference Proceeding Series. https://doi.org/10.1145/3305160.3305191

Sundberg, L. (2019). Electronic government: Towards e-democracy or democracy at risk? Safety Science. https://doi.org/10.1016/j.ssci.2019.04.030

Susena, E., \& Lestari, D. A. (2016). Efektivitas Penerapan Electronic Government Terhadap Pelayanan Publik Di Kabupaten Sragen. Jurnal SAINSTECH Politeknik Indonusa Surakarta.

Wahyuni, E., Afistha, N. M., \& Nawangsari, R. (2020). MODEL PENINGKATAN PELAYANAN PUBLIK PADA INSTANSI PEMERINTAH DI INDONESIA Enhancement Model of Public Services in Indonesian Government Institutions. 1(April).

\section{UCAPAN TERIMA KASIH}

Penulis mengucapkan terima kasih kepada berbagai pihak yang membantu terwujudnya penelitian dan artikel ini. Penulis mengucapkan terima kasih kepada istri, orang tua, dan adik serta keluarga besar Jurusan Pendidikan Administrasi, Universitas Negeri Yogyakarta

\section{PROFIL PENULIS}

Penulis lahir di Temanggung pada 25 Oktober 1991. Penulis menempuh pendidikan dasar sampai menengah di Temanggung. Kemudian melanjutkan pendidikan S1 di Universitas Diponegoro pada Jurusan Administrasi Publik. Pendidikan magister juga ditempuh di Universitas Diponegoro pada Program Studi Magister Ilmu Administrasi. Saat ini penulis menjadi pengajar di Jurusan Pendidikan Administrasi, Universitas Negeri Yogyakarta. ORCID ID 0000-0002-7246-0378, Google Scholar user=Fx2FTfEAAAAJ\&hl=id, Sinta: 6022758 